\title{
12. Human evolution in Sunda and Sahul and the continuing contributions of Professor Colin Groves
}

\author{
Michael C Westaway, Arthur Durband and David Lambert
}

\section{Introduction}

In terms of understanding evolutionary processes in the human origins story, much can be gained by employing an approach of splitting the known fossil record into numerous taxonomically recognised species. By focusing on variation in fossil specimens, as defined by differences in characters in both time and space, we can start to explore possible evolutionary relationships among the range of fossil specimens. The opposite approach, of lumping such taxonomically species will potentially obscure interesting differentiation, resulting in the possible loss of understanding for important phylogenetic relationships (Groves, 1989a). Whether such taxonomically recognised species are biologically real or not is exceedingly difficult to establish in the fossil record, however, splitting fossils into divisions based on character traits enables the effective testing of hypotheses regarding the validity of such species.

Approaches in Australian palaeoanthropology have largely been characterised by splitting and lumping. For more than 15 years, the charismatic lumper Alan Thorne had carried the day for the evolutionary story of the Australasian region. His interpretation of the evolution of Homo sapiens in our region evoked an argument for deep geological links with regional Homo erectus. It represented a record of regional continuity anchored to the evidence first discovered in Java some 120 years ago (Dubois, 1894). The model was unlike the earlier variants of the regional continuity brand of human evolution, which proposed a direct 'candelabra' treatment of the fossil record. Thorne proposed that there was some limited gene flow between populations from different regions, however, the crux of his argument was that there was general continuity of traits in the regions. There had not been much modification to this regional pattern from outside. For the colonisation of Sahul, Thorne envisaged that there had been two major migrations into Australia, one derived from Ancient China, the other from Ancient Java. His hypothesis was referred to as the dihybrid model of Aboriginal origins. 
With a background in journalism and a multitude of connections, Thorne delivered a powerful $\mathrm{ABC}$ documentary to the nation on human origins in Sunda and Sahul in 1988, known as 'Man on the Rim'. Together with his American colleague Milford Wolpoff and links forged with Chinese and Indonesian colleagues, he was generally very successful in promoting his model of human evolution for the region on the international stage. His partnerships with Indonesian colleagues had helped him obtain an extensive cast collection (now at the Shellshear Museum, University of Sydney) representative of Sunda, which enabled him to draw his comparisons with the available record from Sahul. He added dramatically to our understanding of the Sahul record, and amassed, through an inspiring two decades of fieldwork, an assemblage of Pleistocene remains from Australia that numbered over 100 individuals, from the internationally significant sites of Kow Swamp and the Willandra Lakes (including Lake Mungo). He held a virtual monopoly over the fossil series, and developed strong links with the Willandra Elders to ensure that research could continue on the series, following the scientific disaster of the Kow Swamp reburial. Thorne for these years appeared to reign supreme, but his position was not to last.

In 1974, Colin Groves, fresh from the Duckworth Laboratory of Physical Anthropology at Cambridge, arrived in Australia. His arrival was in time for some quite significant events relating to research on Aboriginal origins. He was present at the time of the excavation of Mungo Man (WLH 3). This taste of Australian fieldwork was soon after followed by the 'Origins of the Australians' conference held in Canberra at the Australian Institute of Aboriginal Studies. At this conference the mandible of Mungo Man, with his extraordinary pattern of occlusal wear, was exhibited. Macintosh commented at the time that it was morphologically within the range of modern Australians (Macintosh and Larnach, 1976). The Canberra conference defined the parameters for much future debate on the origins of the Australians, a debate that we have moved only somewhat closer to answering today.

From these beginnings at The Australian National University, it was here that Groves was to base much of his interpretations of the fossil record for human origins. His contributions to our understanding of human origins have been of international significance. While there is much of importance in his work to discuss, such as his naming of the species Homo ergaster with Mazák (1975), which has helped to make sense of the confusing morphological diversity that is all too often lumped into Homo erectus, this chapter is restricted to a summary of his contributions to our understanding of human origins in Sunda and Sahul. His work on human origins in Sunda and Sahul did not really begin to emerge in print until 15 years after he first had his feet burnt at Lake Mungo, but many publications strongly (and always politely) argued for replacement 
over regional continuity. This chapter will attempt to tie his work into current research and understanding of human evolution in Sunda and Sahul, and in doing so we hope, shall demonstrate how well his science has held up. While the picture seems far more complicated today compared to the original sketch from 1974, encouragingly a great deal more is now known as a result of a series of new discoveries (some of which are nothing short of spectacular) and the development of improved analytical techniques.

In this chapter we shall consider five major themes that Groves has devoted some thought towards, including i) the question of the taxonomic affinity of the first hominins in Sunda, ii) the first crossing of the Wallace Line by archaic hominins, iii) the evolutionary trajectory of Homo erectus (with a focus on the meaning of late derived erectus), iv) the second crossing of the Wallace Line by Homo sapiens resulting in the subsequent colonisation of Sahul, and v) the important new insights that studies of ancient DNA (aDNA) are contributing to our rewriting of the human evolutionary narrative in Sunda and Sahul. We feel that these represent the key topics in human evolutionary studies on our genus within the region, all being topics that Groves has contributed to.

\section{The first Javan hominins: Is there a case for a pre-erectus taxon in Sunda?}

The possibility of an earlier species being present within the lower units of the site of Sangiran, Java, is a proposition that has quite a long history. Von Koenigswald argued that there were two separate species represented in the fossil record of Java, which he called Pithecanthropus erectus and an earlier species Meganthropus palaeojavanicus (von Koenigswald 1956). Indeed Robinson (1953 and 1955) had suggested that the specimens often associated with Meganthropus were best placed within the genus Paranthropus and identified them as a separate species, Paranthropus palaeojavanicus. Certainly when one considers the hyper robust corpus of Sangiran 6 it is reminiscent of the heavy masticatory apparatus of African Paranthropus, a dentition adapted for processing hardy open woodland vegetation.

A significant comparison of these fossils by Philip Tobias and Ralph von Koenigswald (1964) in Cambridge compared the fossils from the African record (primarily Olduvai) with the Javan specimens. They had a particular focus on those fossils that had been termed Meganthropus. The picture that emerged from the study was an identification of four grades of hominisation, with a suggestion that Meganthropus fitted within a grade similar to that of Homo habilis. Later Tyler (1995) in describing the Sangiran 31 calotte suggested that either the range of Homo erectus needed to be redefined or this fossil represented 
a different species, of which Homo habilis is one that he favoured. The extreme occipital torus is well beyond that of any of the Javan specimens, and a strange region of raised bone has been identified as a sagittal crest (Tyler et al., 1995), a description that has been dismissed by Grimaud-Hervé (2001) as being not possible due to the presence of an angular torus. She suggests that the character may instead be a post-mortem anomaly, the feature perhaps representing raised external compact bone.

A study by Kaifu and colleagues (2005) reviewed this proposition, and identified that the specimens that had in the past been recognised as Meganthropus (Weidenreich 1943) supported two evolutionary propositions. Either there had been a great deal more variability in Homo erectus prior to the Middle Pleistocene, or that there may indeed be another species present. One of the key points that Kaifu had made was that there were a number of characters in the jaw fragments that were more like Homo habilis than Homo erectus.

In an article in Australasian Science in 2008 in relation to the taxonomic affinities of Homo floresiensis, Groves discussed the possibility of a connection between the enigmatic fossil and the earliest known hominins from Java. Specifically he asked:

The question is: can we find traces of its ( There are almost no fossils of the relevant time period anywhere between Africa and Java, but in Java itself there are (mostly rather scrappy) remains from levels somewhat earlier than those from which Homo erectus have come. Most authors have considered that these early Javanese fossils also represent Homo erectus, but recently a joint Japanese and Indonesian team, led by the noted palaeoanthropologist Kaifu, have found that they are actually rather different. This raises a question: if there is something different, something non-erectus, in these early levels, could Homo floresiensis have a hitherto unrecognized ancestor among them? (Groves 2008)

This idea was discussed further by Groves and one of his students (Westaway and Groves 2009), where it was suggested that a process of replacement in the evolution of hominins perhaps was a regular pattern in hominin evolution in Sunda. They suggested that the later erectus extinction event, following the arrival of Homo sapiens, was just the next stage of hominin replacement in Java. It was also suggested in this paper that the infant fossil from Mojokerto, dating to sometime around 1.49 Ma (Morwood et al., 2003), may in fact represent a juvenile of this species.

The presence of pre-erectus-like characters in the early Java series is intriguing. At a time when Sunda was not a chain of islands, a savannah corridor up to $150 \mathrm{~km}$ wide (Bird, Taylor and Hunt, 2005) supported a more open fauna. It is 
not unreasonable to imagine that there may have been pre-erectus hominins in the Early Pleistocene occupying the savannah and coastal plains at times when the sea levels were low. Provisionally such a species has been called Homo modjokertensis (Westaway and Groves 2009). The view that Homo modjokertensis is a real taxon requires the discovery of more complete fossils dating to the early to Middle Pleistocene. There is a lot of uncertainty relating to the earlier Sangiran fossils, and it is perhaps time to revisit Robinson's original proposal that Paranthropus may be present in the early Middle Pleistocene in Sunda. Certainly the dimensions of Sangiran 6 seem to fall closer within the range of Paranthropus than Homo erectus (Figure 12.1a-d). While Sunda is on the edge of the range of the genus Homo, there has been somewhere in the vicinity of 1.5 Mya of hominin evolution. The discovery of Homo floresiensis has exposed palaeoanthropologists to a view that there was much greater diversity in hominin species in Sunda than previously considered. Indeed it has been questioned as to whether Homo floresiensis should in fact continue to be included in the genus Homo (Collard and Wood, 2007), which is a point that we shall return to in the next section. Further studies are required to arrive at a clearer understanding of this diversity.

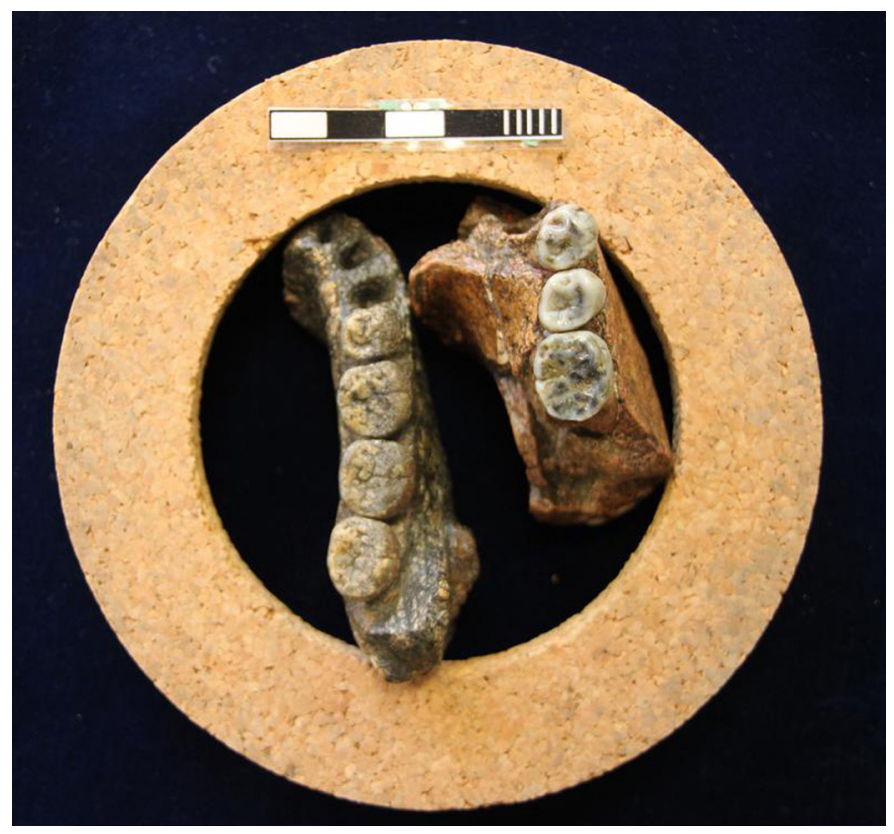

Figure 12.1a: In recent years the Sangiran 6 mandible has been considered by only a few researchers to be outside the range of Homo erectus. The extreme thickness of Sangiran 6 is compared to that of Sangiran $1 b$. 


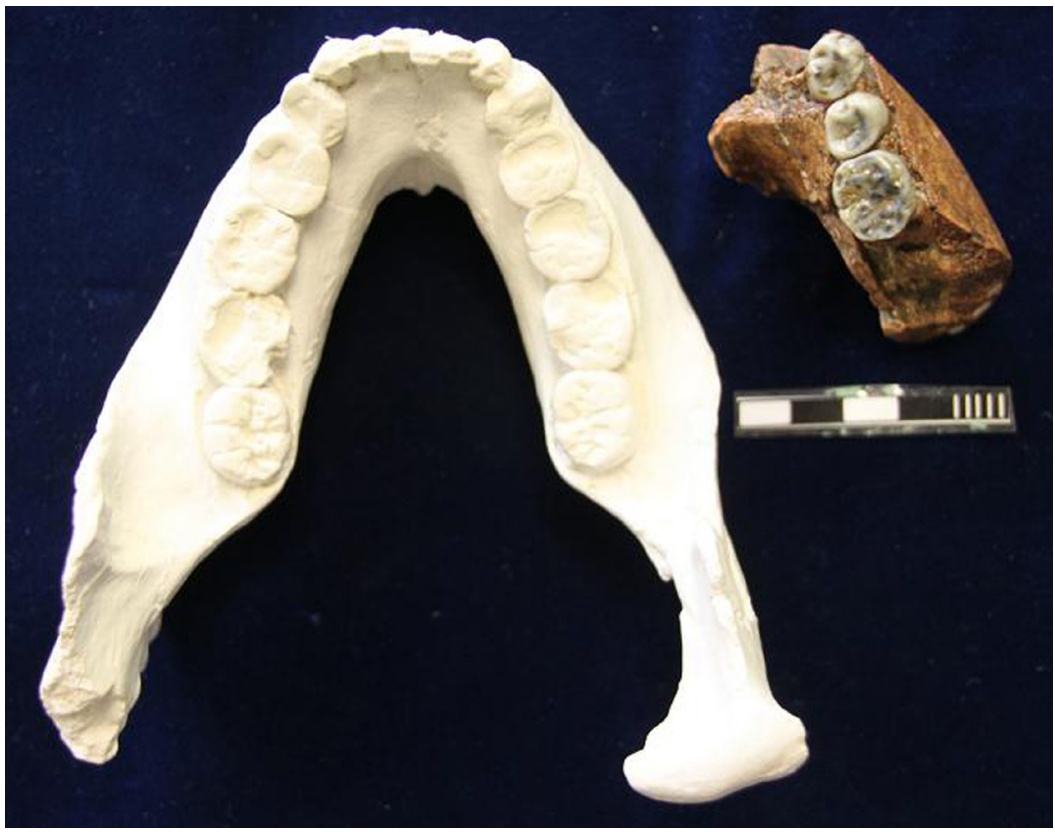

Figure 12.1b: The very thick corpus of Sangiran 6 is similar to that seen in the Peninj Paranthropus mandible.

Source: Photographs taken by Michael Westaway.

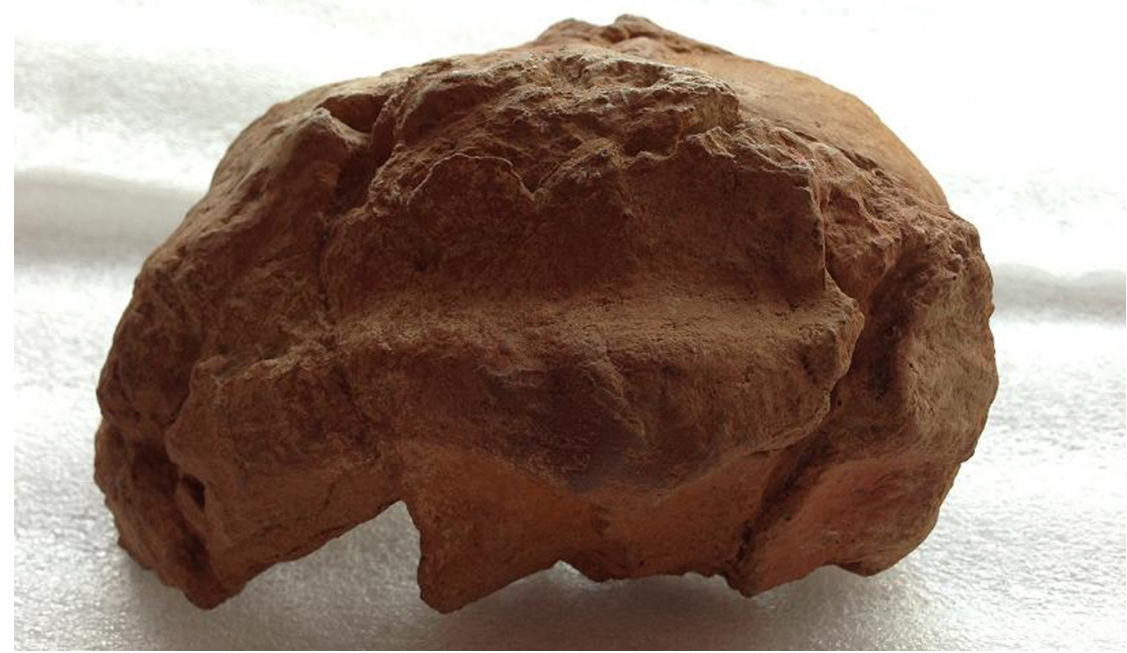

Figure 12.1c: The posterior view of Sangiran 31 (cast) showing the extreme robusticity of the occipital torus.

Source: Photographs taken by Michael Westaway. 


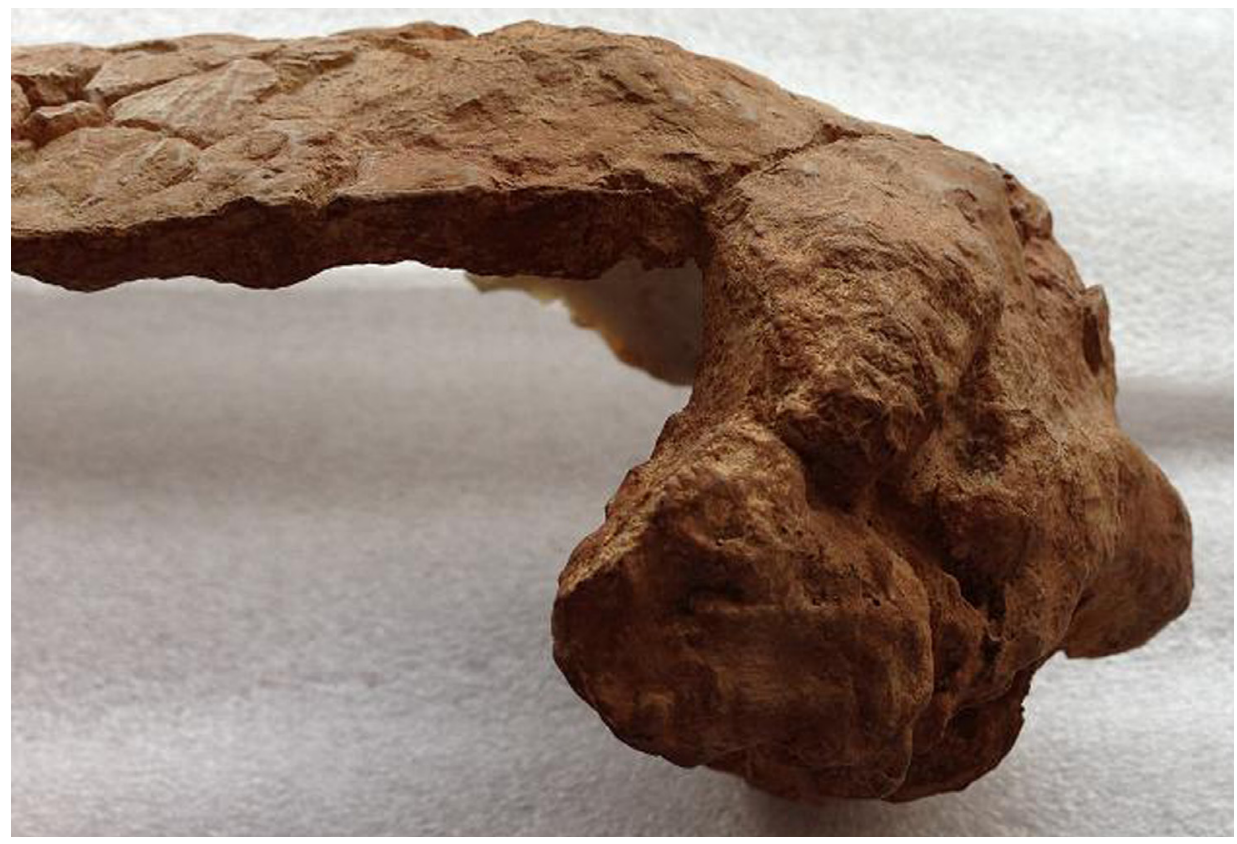

Figure 12.1d: Lateral view of Sangiran 31 (cast) showing the extreme robusticity of the occipital torus.

Source: Photographs taken by Michael Westaway.

\section{Crossing the Wallace Line (1): The puzzle of Homo floresiensis}

The human evolutionary context at the time of Groves' paper 'hovering on the brink' was relatively straightforward. There had been migration into the region by an archaic hominin, Homo erectus, which was later replaced with modern humans. The initial interpretations of the archaeological record from Flores indicated that Homo erectus had made it across the Wallace Line, being present from some $700 \mathrm{ka}$ (Groves, 1996). Groves in this paper discussed evidence from the general palaeontological and zoogeographical record to help build a meaningful context around the stone artefacts from Flores. He suggested that Homo erectus in Flores was part of a general oriental dispersal along the lesser Sunda Chain.

With the discovery of Homo floresiensis the story became far more complicated. Initial interpretations have focused on $H$. floresiensis being derived from $H$. erectus. The principle of island dwarfing has been cited as a possible mechanism of how $H$. erectus may have initially evolved from the larger species (Brown et al., 2004). Revision of the endocranial volume of $H$. floresiensis to $426 \mathrm{cc}$ by 
Kubo et al. (2013) has perhaps made the proposition of dwarfism somewhat more tenable. In their comparison they consider dwarfism from the earlier known hominins from Java, provisionally called here Homo modjokertensis (but lumped by Kaifu and colleagues within Homo erectus). What the most recent study by Kaifu et al. helps establish is that Homo floresiensis may be derived from the earliest hominins known from Sangiran.

Cladistic analyses have suggested that Homo floresiensis is derived from either a Homo rudolfensis or Homo habilis like ancestor, indicating that it is part of a lineage dating back to either the Late Pliocene or Early Pleistocene (Argue et al., 2009). It is important to note at this point that Homo erectus is derived from the much later African species Homo ergaster. The evidence from the post crania also suggests that a pre-erectus hominin is more likely the ancestor for Homo floresiensis. The primitive anatomy of the wrist (Tocheri et al., 2007), the general limb proportions (Holliday and Franciscus, 2009), the pelvis (Jungers et al., 2009a), and the unusual anatomy and proportions of the feet (Jungers et al., 2009b) all seem to support this proposition. Jungers et al. (2009b) make the point that while it is possible that insular dwarfism may have resulted in some reversals to a few plesiomorphic states over a period of $800 \mathrm{ka}$, it is improbable that island dwarfism directed such dramatic change throughout so much of the cranial and postcranial anatomy of Homo floresiensis. One limitation that we face is the absence of fossils representative of the wrist and feet from Homo ergaster and Homo erectus.

It has recently been suggested (Collard and Wood, 2007) that the inclusion of the Late Pleistocene specimens from the site of Liang Bua, Flores, in the genus Homo as a new species, H. floresiensis, is not compatible with the commonly accepted definition of the genus Homo (Wood and Collard, 1999).

\section{Regional continuity in Java: The idea of Homo soloensis}

There has been considerable debate in Europe and Africa regarding the idea of multiple species within the erectus-grade, including such species as Homo antecessor, Homo cepranensis, Homo rhodesiensis and Homo helmei. The idea of intermediate species has been subject to minimal discussion within Sunda. It is possible that the long-term isolation of Java may have led to the formation of new species derived from Homo erectus. 


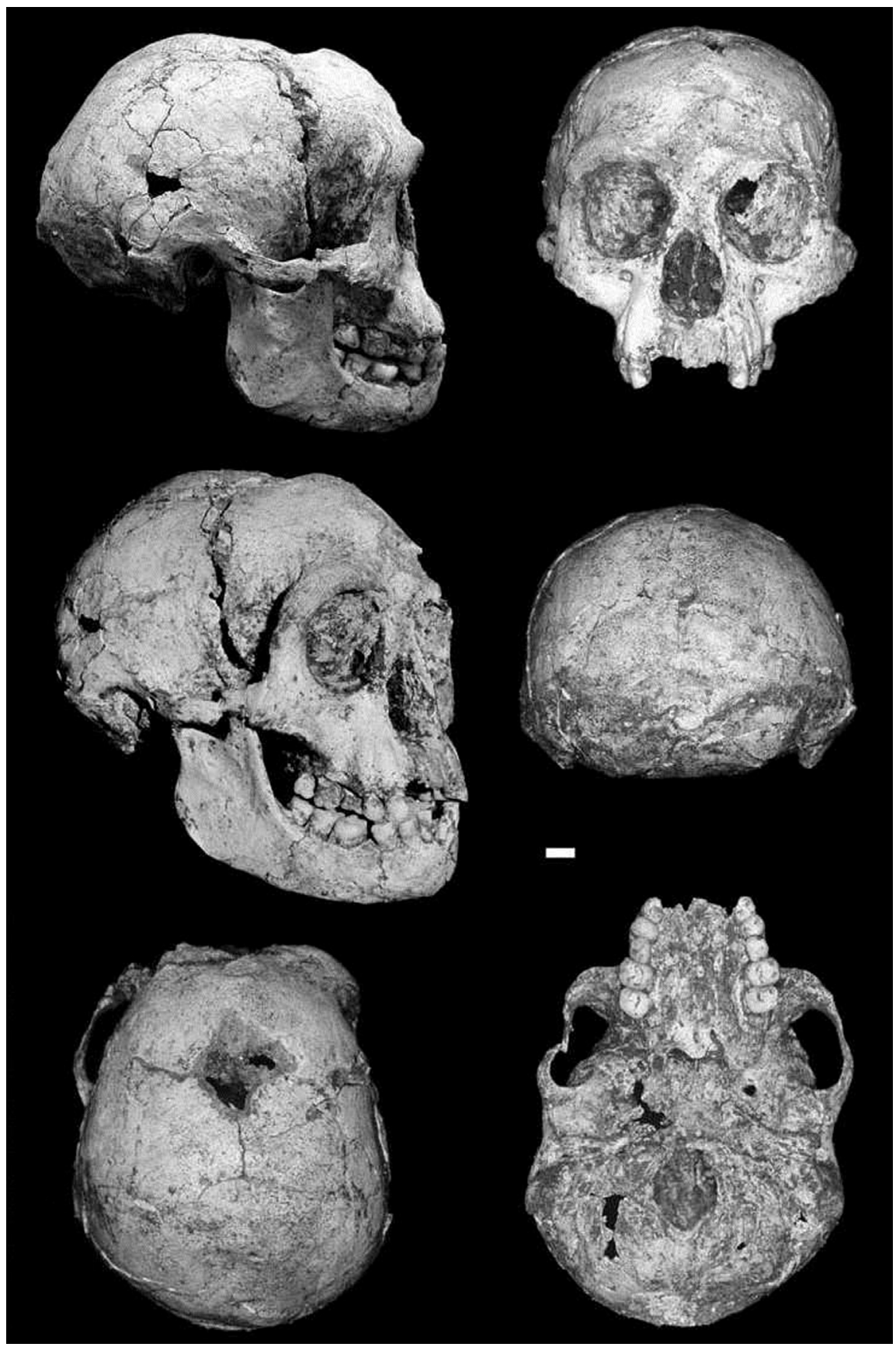

Figure 12.2: Liang Bua 1, the type specimen of Homo floresiensis.

Source: Morwood et al. (2004). 
Alongside discussion around the proposal that archaic Javan Homo erectus (which we called above Homo modjokertensis) had evolved into the diminutive Homo floresiensis, there has also been a less publicised but no less important debate concerning the continuous evolution of Homo erectus in Java. Some workers have suggested that the later surviving individuals from sites like Ngandong and Sambungmacan, often referred to as more 'advanced' Homo erectus (e.g. Santa Luca, 1980; Rightmire, 1990, 1991; Lahr 1996; Anton et al., 2007) or even sometimes as 'archaic' Homo sapiens (e.g. Delson et al. 1977; Bräuer 1992; Frayer et al., 1993), might instead be identified as a new species dubbed Homo soloensis. This species name was coined by Oppenoorth (1932) in his initial descriptions of the earliest hominin material excavated from Ngandong, and has since been reconsidered by more recent authors (e.g. Widianto and Zeitoun, 2003; Zeitoun, 2009; Zeitoun et al., 2010; Durband, 2004, 2007, 2008c, 2009; Durband and Westaway, 2013). Groves (1989a) also recognised the more derived affinities of the later Javan material, referring it to its own chronosubspecies of H. erectus soloensis.

Kaifu and colleagues (2008) provided a detailed analysis of the evolutionary changes that accumulated in the Javan hominin lineage. Those authors recognised 'a continuous, gradual evolution of Javanese $H$. erectus from the Bapang-AG to Ngandong periods' (Kaifu et al., 2008: 578), with the Sambungmacan specimens reflecting a more intermediate morphological condition. These conclusions have been echoed by Zeitoun (2009; Zeitoun et al., 2010), and Durband (2002, 2004, 2007, 2009), who likewise found ample evidence for the accumulation of significant change within the Javanese hominin assemblage. These changes include both morphometric relationships of various cranial elements (e.g. Kaifu et al., 2008) as well as the evolution of several autapomorphic features of the cranial vault and base (Durband, 2002, 2004, 2007, 2008c). Features such as a divided foramen ovale located in a pit, the unique configuration of the mandibular fossa, and a 'teardrop' shaped foramen magnum caused by an opisthionic recess are some of the characters that have been shown to be autapomorphic in Ngandong, with most appearing in Sambungmacan and Ngawi (Durband 2004, 2007, 2008c). The faunal record of Java during this time period is indicative of relative isolation and endemism (de Vos et al., 1994; van den Bergh et al., 1996, 1999, 2001), which would be consistent with the interpretations of the patterns seen in the hominins.

While opinions vary on how to approach the taxonomy of the later Javan material (e.g. Ngandong, Sambungmacan, and Ngawi), it is becoming clear that the evolutionary history of the later Sunda hominins is considerably more complex than it is often portrayed. This evidence, particularly when considered alongside the potential for dynamic change suggested by the earliest Javan fossil material and $H$. floresiensis, suggests that there may have been more changes taking place in Sunda than has previously been appreciated. It would seem reasonable to suggest that further speciation occurred in Sunda and there was not overall stasis within the erectus grade, but in fact significant episodes of divergence at certain points in the Pleistocene within two hominin lineages. 


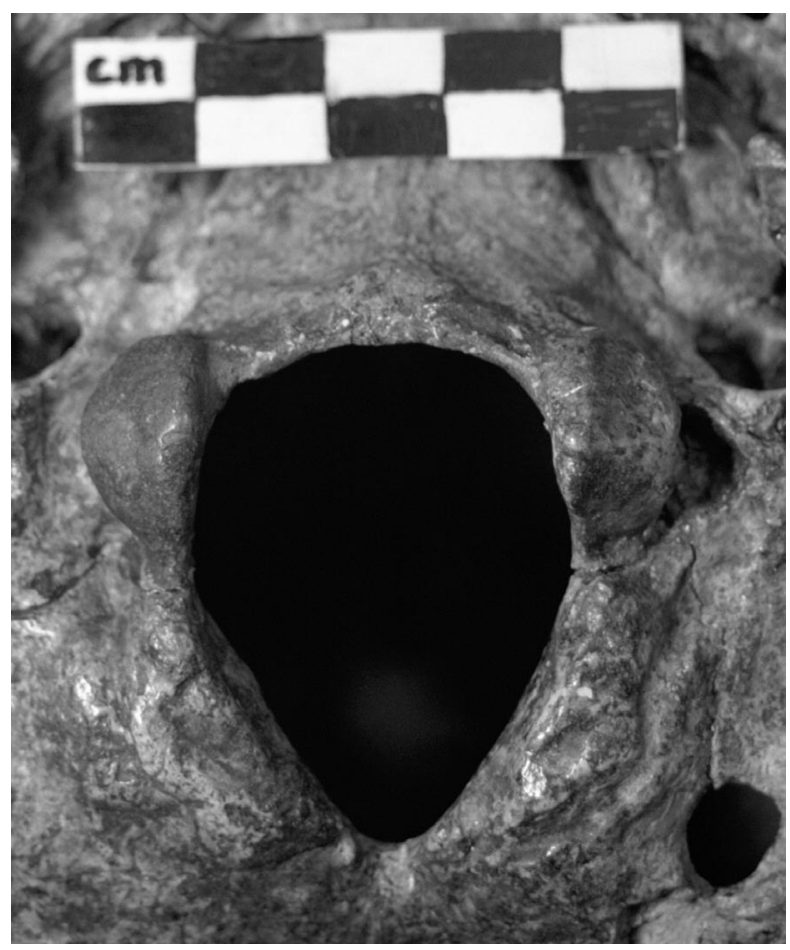

Figure 12.3a: Autapomorphic characters identified in the Ngandong series, including (a) a tear drop shaped foramen magnum (above) and (b) a divided foramen ovale (below).

Source: Photographs taken by Arthur Durband.

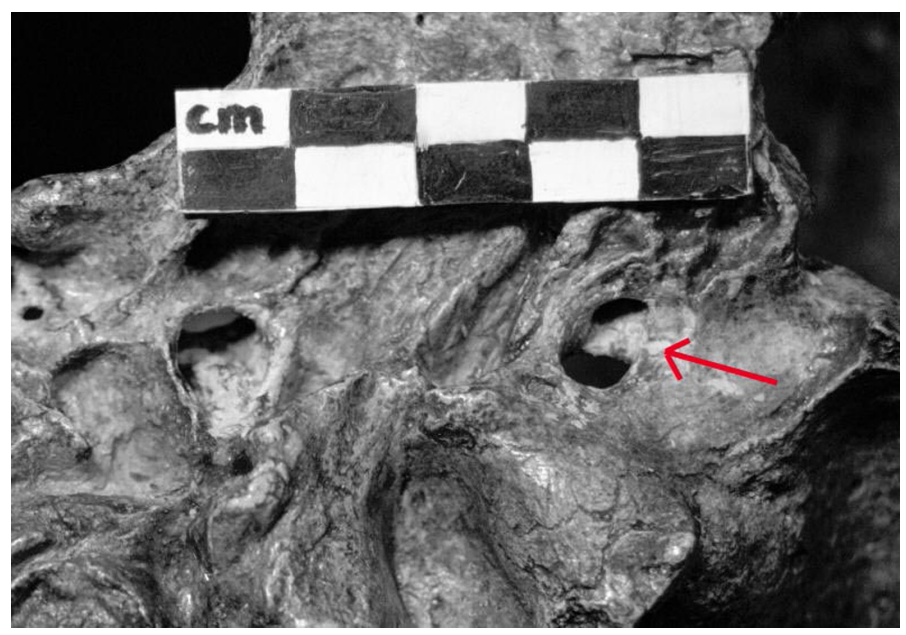

Figure 12.3b 
Taxonomic Tapestries

\section{Crossing the Wallace Line (2): Colonisation of Sahul and morphological variation in Homo sapiens}

The most successful migration through Sunda was that of Homo sapiens. The nature of this migration is now far better understood than it was in 1996, and the complexity of the migration is increasingly being revealed through studies from both ancient DNA (aDNA) and the DNA of modern populations (a topic which will be discussed in further detail in the next section of this paper). The evolution of Homo erectus/soloensis was probably interrupted with the arrival of Homo sapiens in the region, but our understanding of any possible overlap is still imprecise. It is possible that $H$. sapiens migrating into Sunda did not encounter any populations of $H$. erectus/soloensis, as some evidence suggests that they may have become extinct tens of thousands of years earlier (Storm, 2000, 2001 b; see also new dates for Ngandong by Indriati et al., 2011). Certainly the replacement of erectus/soloensis occurred either prior to, or soon after (perhaps a matter of millennia), the arrival of Homo sapiens. It is unclear if Homo sapiens then took the southern route or the northern route to Sahul. The southern route would have brought them into contact with Homo floresiensis, but the earliest evidence on Flores for $H$. sapiens subfossil remains is only early Holocene in age. We still currently lack the evidence necessary in Flores to understand the interaction between these two species. In nearby Timor evidence exists for deep sea fishing activity, identified as that of modern humans, as early as $42 \mathrm{ka}$ (O'Connor et al., 2011).

Homo sapiens developed as part of their cultural repertoire the capacity for long sea journeys, enabling the establishment of a viable population in Australia some 50,000 years ago. While a model identifying a significant genetic contribution from Homo erectus to the origin of the First Australians has been proposed in a number of formats (Thorne, 1976; Thorne and Wolpoff, 1981; Curnoe and Thorne, 2006; Webb 2006), phylogenetic analyses have demonstrated that no such signature can be demonstrated (Westaway and Groves, 2009). Homo erectus has a series of autapomorphic characters distinct to that species, while characters shared between Homo heidelbergensis and Homo sapiens are absent in Homo erectus (Groves and Lahr, 1994). Plesiomorphic retentions in Homo sapiens provide a clearer ancestral link to the earliest anatomically modern fossils from East Africa (Groves, 1989b).

Much of the debate in Sahul on the origins of the First Australians has focused around the meaning behind the Pleistocene robust and gracile fossil series from southeast Australia. Groves (2001) noted that it is expected that much of this variation is the result of evolutionary change over '60 ka' (we prefer a date of $50 \mathrm{ka}$ from available evidence). The suggestion that cranial robusticity 
is representative of adaptation to the climatic stress of the Last Glacial Maximum (LGM) has been the subject of attention by a number of Australian palaeoanthropologists (Wright, 1976; Bulbeck, 2001; Stone and Cupper, 2003; Westaway and Lambert, 2013), although there remains a lack of clarity as to what the actual mechanism for such selection may be. It would seem that in the very important Willandra Lakes series cranial robusticity does not emerge until the approach to the Last Glacial Maximum (Westaway and Groves, 2009). There are five well-dated specimens that support this hypothesis. Currently these include the gracile fossils WLH1 and WLH3 dated to sometime around $40 \mathrm{ka}$ (Olley et al., 2006), and the robust fossils WLH 50 (Grün et al., 2011) and the two fossils WLH 152 and 153 (Webb, 2006). The revised dates on the Kow Swamp cranial series also place this robust series of crania at the peak of the LGM (Stone and Cupper, 2003).

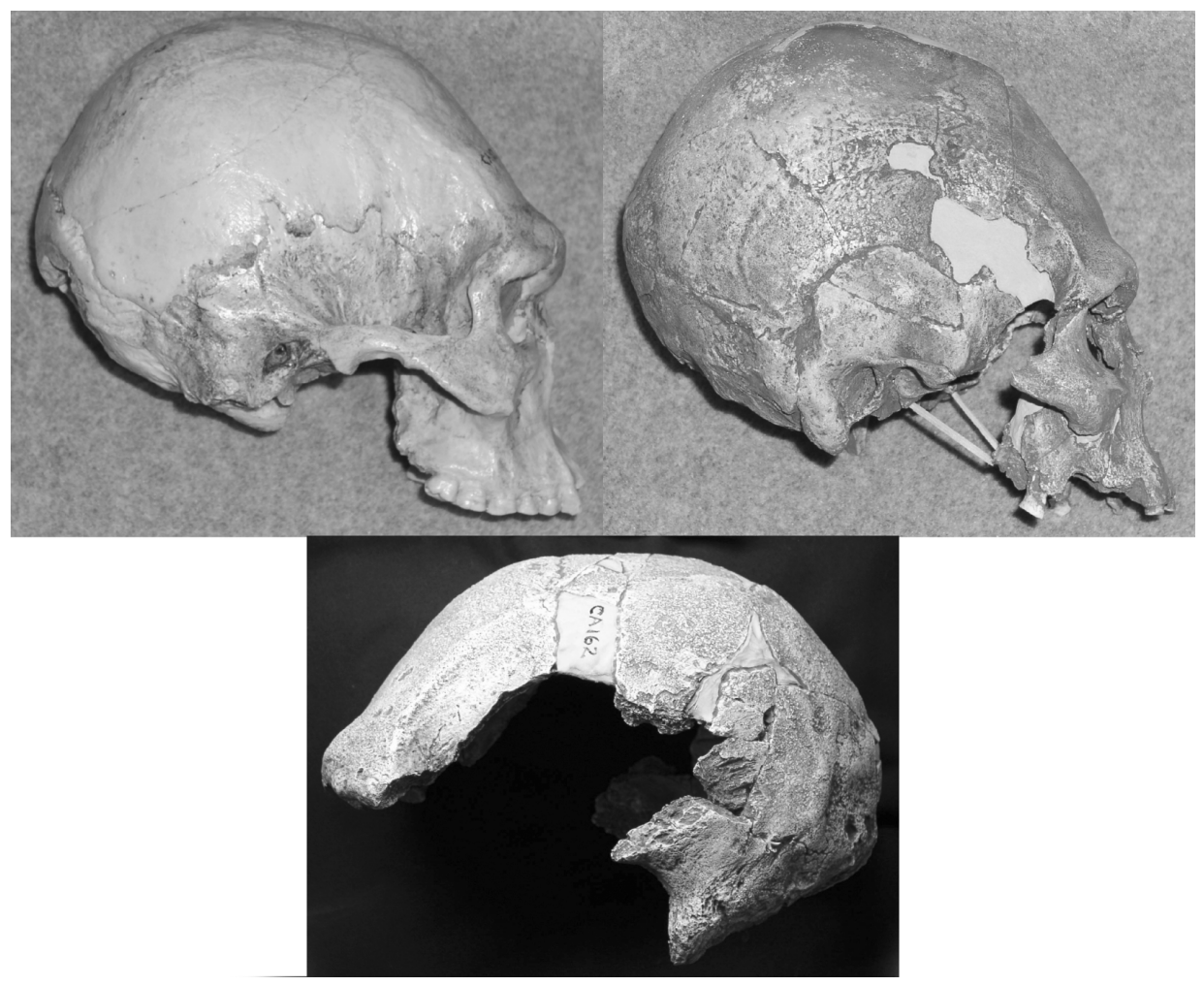

Figure 12.4a: Robust (Cohuna, Kow Swamp 5 and WLH 50) Australian fossils often discussed in the Aboriginal origins debate.

Source: Photographs taken by Arthur Durband. 


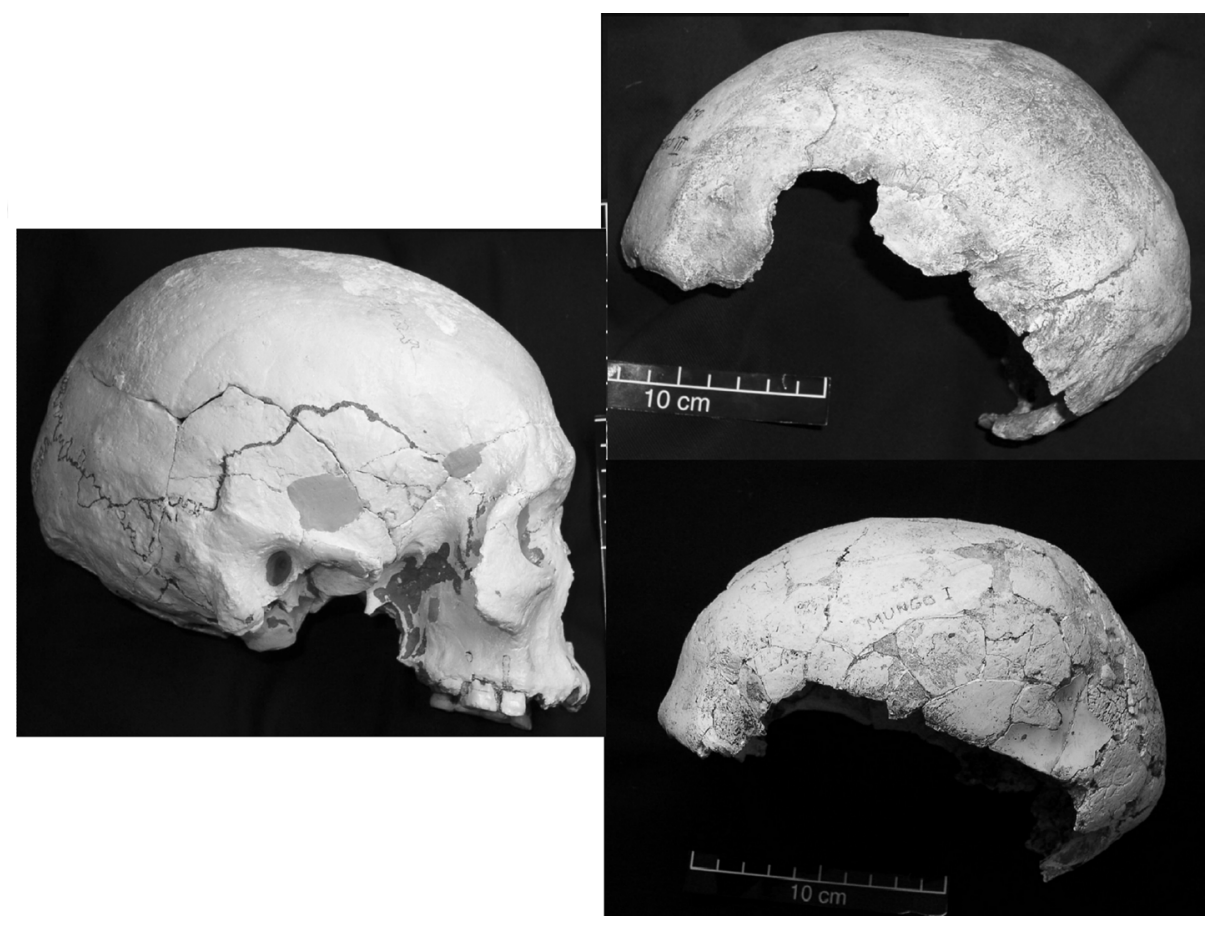

Figure 12.4b: Gracile (Keilor, WLH 3 and WLH 1) Australian fossils often discussed in the Aboriginal origins debate.

Source: Photographs taken by Arthur Durband.

Groves (2001) suggested that increased robusticity was also an artefact of artificial cranial deformation, a prospect that has been demonstrated by a number of workers (Antón and Weinstein, 1999; Durband, 2008ab). Cranial deformation contributed to the appearance of a flattened receding frontal in many of the robust fossils commonly mentioned in this debate; a feature that was initially considered to be a trait inherited from Homo erectus. While it is certainly true that not all of the robust fossils have been artificially deformed, many of the key fossils commonly mentioned by continuity advocates, like Kow Swamp 1, 5, and Cohuna, have been influenced by this cultural practice (Brown, 1989; Durband, 2008ab). Another key robust fossil in the debate, WLH 50, is likely pathological, which has resulted in the increased cranial vault thickness of the individual (Webb, 1990). There does remain some debate regarding the pathological diagnosis of WLH 50 (Westaway, 2006; Curnoe and Green, 2013; Durband and Westaway, 2013).

What would appear to best explain the high degree of cranial variation and the emergence of cranial robusticity is a significant amount of in situ evolution, associated with the climatic amelioration of the LGM, with a very ancient 
example in some regions of Sahul of the cultural practice of cranial deformation. What remains puzzling, however, is the fact that some of the robust fossils in the Australian record, such as WLH 50, WLH 19, Nacurrie 1 and 2, Kow Swamp 5 etc., do bear resemblance to some of the earliest, quite robust fossils from East Africa, such as Herto, Omo I and II and Jebel Irhoud I. This can be extended to early Homo sapiens fossils found outside of Africa as well, such as the fossil Skhul V. When tested phylogenetically (Westaway and Groves, 2009) these robust, circa 100 ka Homo sapiens fossils do sit closely to the more robust specimens from the Willandra Lakes. This suggests a situation where robusticity is present in early Homo sapiens, then a gracile from emerges with the Mungo and Niah individuals, and then we see a return to robust forms around the LGM in the Willandra Lakes.

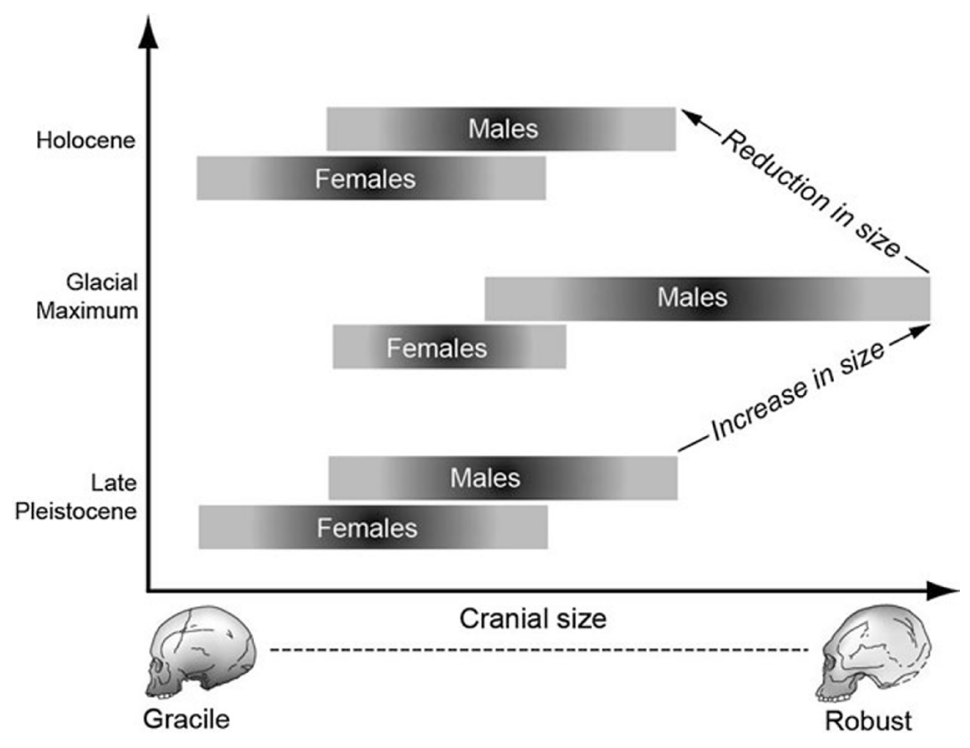

Figure 12.5: Theorised representation of the emergence of cranial robusticity associated with the onset of the Last Glacial Maximum.

Source: Westaway and Lambert (2014).

One of the big questions we now face relates to whether there was significant gene flow into Sahul later in the Pleistocene following the initial colonisation event some $50 \mathrm{ka}$. Oppenheimer (2004) suggested that a secondary migration may in fact explain the appearance of a more robust cranial form in Sahul during the LGM, which is not dissimilar to the earlier models put forward by Thorne. This is a question that is currently the subject of some scrutiny by those interested in the study of DNA. Such a migration has been suggested much later in prehistory, with the identification of gene flow from India occurring in the mid Holocene, said to have coincided with the arrival of the dingo (Pugach 
et al., 2013). This hypothesis will undoubtedly be the subject of reassessment through future studies of both aDNA and modern sampling, which we shall touch upon in the next section.

\section{Revising the record through studies in DNA}

DNA is rewriting our understanding of the complexity of Australia's early population history. It also serves as a catalyst to reconsider the meaning of the diversity in the Australian human fossil and osteological record. Studies on living populations have distinguished unique Y chromosome and mtDNA haplotypes in Aboriginal Australia which indicate that migrations into Australia through Asia predate 50 ka (Keinan et al., 2007; Gutenkunst et al., 2009; van Holst Pellekaan, 2013). However, like all other non-African populations, all Aboriginal Australian mtDNA studies demonstrate that their ancestry can be traced to a single L3 haplotype.

Initial forays into ancient DNA (aDNA) generated much excitement in archaeological/palaeoanthropological circles. The announcement in 2001 by Adcock et al. of the identification of an extinct mitochondrial lineage brought Lake Mungo once again into the global limelight. Their argument suggested that the $40 \mathrm{ka}$ WLH 3 fossil and a later fossil from Kow Swamp (KS 8) contained a non-L3 mitochondrial lineage that was identified as no longer being present in modern populations. This suggested to the authors that two populations had co-existed in Australia, with the WLH 3 mitochondrial genome representing an extinct human lineage (Adcock et al., 2001). In a forum in Archaeology in Oceania, Groves noted that the triumph of the paper, that being of aDNA extraction from such ancient fossils, was overshadowed by what he regarded as the shortcomings of the authors' interpretations. His concerns were over the lack of support for the branch in their cladogram for modern humans and the other potential interpretations of the data (such as the lineage sorting within an ancient population, as opposed to the replacement of a human lineage). In a later publication he discussed with the palaeoanthropologist David Cameron the possibility of contamination in the sequence by nDNA inserts (numts), which may have resulted in the observed mtDNA sequence. They also questioned as to whether the signature represented modern contamination (Cameron and Groves, 2004).

The meaning of the aDNA record from the Willandra series is undergoing a new analysis using next generation sequencing, and a review of this more recent DNA research is providing new insights into the evolutionary past of the first Australians. The identification of archaic DNA of Neanderthals and Denisovans in the DNA of Melanesian populations has revealed that there was indeed 
genetic exchange between the first modern humans in Central Asia and some of the later archaic hominin species during the Late Pleistocene period (Rasmussen et al., 2011). While we have evidence that some limited DNA sequences of Neanderthals and Denisovans were assimilated into H. sapiens, it is feasible that interactions with Homo erectus/soloensis did occur, but no viable offspring resulted. The divergence from Homo erectus was several hundred thousand years earlier than the split between Homo sapiens and Homo neanderthalensis (the recognised common ancestor between the latter two being Homo heidelbergensis, which lived during the later Middle Pleistocene). Low rates of Neanderthal and Denisovan DNA can be interpreted in a number of ways. Perhaps reproductive success was not high and hence it is reasonable to assume that reproductive success would have been even less likely between Homo sapiens and Homo erectus. Current evidence suggests that there is no support for overlap between these two species (Westaway and Groves, 2009; Indriati et al., 2011).

An important component of mtDNA studies from Melanesia (Friedlaender et al., 2005), as highlighted by Davidson (2010 and 2013), is that the genetic evidence indicates two possible migration events, with a separation between the mtDNA of the colonists of north and east Papua New Guinea, with those from southern Sahul. Indeed it would appear that the haplotypes from Melanesia represent earlier haplotypes from those present in southern Sahul (Merriwether et al., 2005). The Australian mt haplogroups S, O, and M42a are not shared with New Guinea on current evidence and this, together with shared haplogroups $\mathrm{P}$ and $\mathrm{Q}$, has been interpreted as indicating separate origins of Australian and New Guinea people, while at the same time suggesting different migration histories of these separate groups of colonisers.

More recent research has identified a genomic signature said to be representative of substantial gene flow between the Indian populations and Australia during the mid Holocene some 4,230 years ago (Pugach et al., 2013). This research group attempted to link these changes with the arrival of the dingo in Australia and the appearance of changes in stone tool technology. However, the latter of these changes have been demonstrated by archaeologists to have occurred much earlier in some regions of Australia (Hiscock, 2008), and are likely to have little relevance to a possible migration from India. The other key issue with the proposed Indian migration is how did such populations enter Australia in the mid Holocene without leaving any trace in island Southeast Asia? While an influx of additional genetic material into Australia during the Holocene possibly did occur, it is still not clear if this left any significant genetic signature. This question will require further review to establish the meaning of any such genetic signature. 
Taxonomic Tapestries

\section{Discussion}

Colin Groves has made a significant contribution to our understanding of human evolution in Sunda and Sahul. One aspect of human evolution in the region that all would seem to agree upon is that resolving many of the questions discussed in the past by Groves and others will only be possible through the discovery of new specimens. Importantly, it also requires a clearer chronological sequence for the fossils, in order to place them reliably in an evolutionary framework. Refining our techniques of analysis is critical to help establish more reliable means of hypothesis testing. An approach that involves splitting fossil specimens into different taxonomically recognised species (or operationally taxonomic units, as Groves prefers) holds a great deal of potential for unravelling the nature of phylogenetic relationships in human evolution. If species are lumped together, and autapomorphies in recognisable specimens are effectively ignored, then we risk the opportunity of identifying examples of speciation within our genus.

In this chapter we have considered a number of key themes in human origins research in the regions of Sunda and Sahul. The taxonomic subdivision of various fossil discoveries of Sunda spanning some 1.5 million years into four separate species (as opposed to two) is an approach that is currently difficult to test phylogenetically, due to the fragmentary nature of the early Sangiran record. As demonstrated by Kaifu et al., it is difficult to establish with certainty if the pre-Grenzbank fossils from Sangiran truly represent a distinct species. Kubo et al. (2013) have recently demonstrated that dwarfism in Homo floresiensis is a less dramatic prospect when we consider this with the earlier Javan hominins, and not the later classic Homo erectus. Previously Kaifu et al. (2005) have raised the possibility that the earlier Javan hominins may in fact represent an earlier species. We envisage that perhaps a more parsimonious explanation for the origins of Homo floresiensis is that it is derived from an earlier pre-erectus hominin. We agree that the pre-Grenzbank fossils probably represent a more likely candidate ancestor for Homo floresiensis, or perhaps a sister group to a close ancestor, than do the later Homo erectus fossils. There are some fossils from the pre-Grenzbank, such as the very large Sangiran 6 that may even represent a different genus, as suggested by Robinson (1953 and 1955). Sangiran 6 is unlikely to represent an ancestor of either Homo floresiensis or Homo erectus. It is probable that it was the gradual divergence between species within these different populations, following the geographic isolation of one population on Flores, which led to the emergence of the new species Homo floresiensis. In this model then Homo modjokertensis was not necessarily a terminal species, and it was also not the ancestor of Homo erectus. The ancestral candidate for Homo erectus was Homo ergaster. We suggest that Homo modjokertensis on Java was eventually replaced by Homo erectus, the timing of which remains unknown. 
Is it reasonable to continue identifying Homo erectus as a distinct species that remained as the same taxon for around 1 Mya-800 ka? Homo erectus continued along its evolutionary trajectory following the extinction of Homo modjokertensis. If the species evolved on Java for $800 \mathrm{ka}$ or more, should we regard the late Homo erectus at the sites of Ngandong, Ngawi and Sambungmacan as a different species? Similar divisions have been made within the transitory grade between Homo heidelbergensis and Homo neanderthalensis. There is an increasing acceptance of evolutionary change within hominin species that did not necessarily lead to the lineage of Homo sapiens. This perhaps requires for consideration the designation of a later species Homo soloensis.

The presence of Homo floresiensis in the lesser Sunda Islands suggests that hominin evolution on the edge of the hominin range was no less stagnant than evolution in other regions closer to the original centre. Perhaps it is time that we begin considering that evolutionary processes in Sunda are as complex as those identified in Africa and Europe, with a model of punctuated equilibrium perhaps being relevant to Pleistocene Sunda. Homo soloensis was eventually replaced by Homo sapiens sometime after 100,000 years ago. Homo floresiensis was replaced soon after the arrival of Homo sapiens in the lesser Sunda Chain, following the arrival of modern people on the eastern side of the Wallace Line, perhaps some 60,000 years ago. It is apparent that our species was likely responsible for the extinction of two hominin lineages in Sunda, although the timing of the disappearance of Homo erectus remains unresolved.

Microevolutionary changes are most likely responsible for the variation that we see within Homo sapiens in Pleistocene Sahul. It would not appear necessary to call upon models that discuss assimilation of Sunda hominins to explain the appearance of cranial robusticity around the time of the Last Glacial Maximum. The emergence of cranial robusticity perhaps has more to do with the onset of glacial conditions in Sahul. DNA studies may be able to assist us in unravelling the gracile and robust debate, by establishing if the variation is simply just reflective of sexual dimorphism. Importantly, DNA is beginning to reveal important new information that is not available from the study of fossil morphology alone. The evidence for genetic exchange between our species and the Late Pleistocene hominins Homo neanderthalensis and the enigmatic Denisovans is an exciting development resulting from such studies.

\section{Conclusion}

We are very fortunate that amongst his diverse taxonomic interests Colin Groves has been able to invest some time into the question of hominin phylogeny in Sunda and Sahul. The discipline in Australia is very much richer as a result. 
In this paper we have suggested a hypothesis for hominin evolution in Sunda and Sahul building on the theoretical approach of Groves. It will be tested, and potentially falsified, through the acquisition of new evidence (both fossil and DNA), the refinement of the chronology of known fossil hominins, and the development of new techniques of phylogenetic analysis on both new and old data.

\section{Acknowledgements}

Thank you very much to the editors for their kind invitation to be part of this important volume. We are grateful to Dr Christine Hertler and Dr Friedemann Schrenk from the Senckenberg, Frankfurt, for providing access to the Sangiran 6 specimen in their collection and allowing me to compare these to casts within the collection. We are also grateful to Dr Dominique Grimaud-Hervé from The Institut de paléontologie humaine, Paris, for allowing MCW access to the cast of Sangiran 31 and for discussions on the possible meaning of its morphology. Professor Mark Collard from Simon Fraser University provided many valuable comments on the possible meaning of the Sangiran 6 mandible, a jaw fragment that we hope to review with Prof Collard in further detail at some stage in the future. The Elders from the Willandra Lakes World Heritage Area have provided ongoing support for our research into the origin of their ancestors, which we are deeply grateful for. Finally, the late Professor Mike Morwood provided the images of Homo floresiensis, he was a very generous and supportive scholar and the discipline of palaeoanthropology in this region has suffered a great loss with his passing.

\section{References}

Adcock GJ, Dennis ES, Easteal S, Huttley GA, Jermiin LS, Peacock J, Thorne A. 2001. Mitochondrial DNA sequences in ancient Australians: Implications for modern human origins. Proc Natl Acad Sci 98(2):537-542.

Anton SC, Spoor F, Fellman CD, Swisher III CC. 2007. Defining Homo erectus: Size considered. In: Henke W, Tattersall I, editors. Handbook of Paleoanthropology. Berlin: Springer-Verlag. pp. 1655-1693.

Antón SC, Weinstein KJ. 1999. Artificial cranial deformation and fossil Australians revisited. J Hum Evol 36:195-209.

Argue D, Morwood MJ, Sutikna T, Jatmiko, Saptomo EW. 2009. Homo floresiensis: A cladistic analysis. J Hum Evol 57:623-629. 
Bird MI, Taylor D, Hunt C. 2005. Palaeoenvironments of insular Southeast Asia during the Last Glacial Period: A savanna corridor in Sundaland? Quat Sci Rev 24(20-21):2228-2242.

Bräuer G. 1992. Africa's place in the evolution of Homo sapiens. In: Bräuer G, Smith, editors. Continuity or replacement: Controversies in Homo sapiens evolution. Rotterdam: AA Balkema. pp. 83-98.

Brown P. 1989. Coobool Creek. A morphological and metrical analysis of the crania, mandibles and dentitions of a prehistoric Australian human population. Terra Australis, 13. Canberra: Department of Prehistory, Australian National University.

Brown P, Maeda T. 2009. Liang Bua Homo floresiensis mandibles and mandibular teeth: A contribution to the comparative morphology of a new hominin species. J Hum Evol 57:571-596.

Brown P, Sutikna T, Morwood MJ, Soejono RP, Jatmiko Wayhu Saptomo E, Awe Due R. 2004. A new small-bodied hominin from the Late Pleistocene of Flores, Indonesia. Nature 431:1055-1061.

Bulbeck FD. 2001. Robust and gracile Australian Pleistocene crania: The tale of the Willandra Lakes. In: Simanjuntak T, Prasetyo B, Handini R, editors. Sangiran: Man, culture, and environment in Pleistocene times: Proceedings of the International Colloquium on Sangiran Solo-Indonesia. Jakarta: Yayasan Obor. pp. 60-106.

Cameron DW, Groves CP. 2004. Bones, stones and molecules. London: Elsevier.

Collard M, Wood BA. 2007. Defining the genus Homo. In: Henke W, Rothe H, Tattersall I, editors. Handbook of Paleoanthropology. Berlin Heidelberg: Springer. pp. 1575-1610.

Curnoe D, Thorne A. 2006. Human origins in Australia: The skeletal evidence. Before Farming [online version] 2006/1 Article 5.

Curnoe D, Green H. 2013. Vault thickness in two Pleistocene crania. J Archaeol Sci 40(2):1310-1318.

Davidson I. 2010. A lecture by the returning Chair of Australian Studies, Harvard University, 2008-09 Australian archaeology as a historical science. $J$ Australian Studies 34(3):377-398.

Davidson I. 2013. Peopling the last new worlds: The first colonisation of Sahul and the Americas. Quatern Int 285:1-29. 
Taxonomic Tapestries

Delson E, Eldridge N, Tattersall I. 1977. Reconstruction of hominid phylogeny: A testable framework based on cladisitic analysis. J Hum Evol 6:263-278.

de Vos J, Sondaar PY, Van Den Bergh GD, Aziz F 1994. The Homo bearing deposits of Java and its ecological context. Cour Forsch Inst Senckenberg 171:129-140.

Dubois E. 1894. Pithecanthropus erectus, eine menschenaehnliche Ubergangsform aus Java. Batavia: Landesdruckerei.

Durband AC. 2002. The squamotympanic fissure in the Ngandong and Sambungmacan Hominids: A reply to Delson et al. Anat Rec 266:138-141.

Durband AC. 2004. A test of the multiregional hypothesis of modern human origins using basicranial evidence from Indonesia and Australia. PhD dissertation, University of Tennessee.

Durband A. 2006. Craniometric variation within the Pleistocene of Java: The Ngawi 1 cranium. Hum Evol 21:193-201.

Durband A. 2007. The view from down under: A test of the multiregional hypothesis of modern human origins using the basicranial evidence from Australasia. Collections in Anthropology 3:651-659.

Durband AC. 2008a. Artificial cranial deformation in Pleistocene Australians: The Coobool Creek sample. J Hum Evol 54(6):795-813.

Durband AC. 2008b. Artificial cranial deformation in Kow Swamp 1 and 5: A response to Curnoe (2007). Homo 59:261-269.

Durband AC. 2008c. Mandibular fossa morphology in the Ngandong and Sambungmacan fossil hominids. Anat Rec 291:1212-1220.

Durband AC. 2009. Southeast Asian and Australian paleoanthropology: A review of the last century. J Anthropol Sci 87:7-31.

Durband AC, Westaway MC. 2013. Perspectives on the origins of modern Australians. In: Smith FH, Ahern J, editors. The origins of modern humans: Biology reconsidered. Wiley-Blackwell.

Frayer DW, Wolpoff MH, Thorne AG, Smith FH, Pope GG. 1993. Theories of modern human origins: The paleontological test. Am Anthropol 95:14-50.

Friedlaender J, Schurr T, Gentz F, Koki G, Friedlaender F, Horvat G, Babb P, Cerchio S, Kaestle F, Schanfield M, Deka R, Yanagihara R, Merriwether DA. 2005. Expanding southwest Pacific mitochondrial haplogroups $\mathrm{P}$ and Q. Mol Biol Evol 22:1506-1517. 
Grimaud-Hervé D. 2001. Taxonomic position of the Sangiran 31 Hominid. In: Simanjuntak T, Prasetyo B, Handini R, editors. Sangiran: Man, culture, and environment in Pleistocene times: Proceedings of the International Colloquium on Sangiran Solo-Indonesia. Jakarta: Yayasan Obor. pp. 46-53.

Groves CP. 1989a. A theory of human and primate evolution. Cambridge: Cambridge University Press.

Groves CP. 1989b. A regional approach to the problem of the origin of modern humans in Australia. In: Mellars PA, Stringer CB, editors. The human revolution: Behavioural and biological perspectives on the origins of modern humans. Edinburgh: Edinburgh University Press. pp. 274-285.

Groves CP. 1996. Hovering on the brink but not quite getting there. Perspect Hum Biol 2:83-87.

Groves CP. 2001. Lake Mungo 3 and his DNA. Archaeol Ocean 36(3):166-167.

Groves, CP 2008. Walking with Hobbits. Australasian Science (March):16-19.

Groves CP, Lahr MM. 1994. A bush not a ladder: Speciation and replacement in human evolution. Perspect Hum Biol 4:1-11.

Groves CP, Mazák V. 1975. An approach to the taxon of Hominidae: Gracile Villafranchian hominids of Africa. Casopsis Pro Mineralogii 20:225-246.

Grün R, Spooner N, Magee J, Thorne A, Simpson J, Yan G, Mortimer G. 2011. Stratigraphy and chronology of the WLH 50 human remains, Willandra Lakes World Heritage Area, Australia. J Hum Evol 60(5):597-604.

Gutenkunst RN, Hernandez RD, Williamson SH, Bustamante CD. 2009. Inferring the joint demographic history of multiple populations from multidimensional SNP frequency data. PLoS Genetics 5(10):e1000695.

Hawks J, Oh S, Hunley K, Dobson S, Cabana G, Dayalu P, Wolpoff MH. 2000. An Australasian test of the recent African origin theory using the WLH-50 calvarium. J Hum Evol 39:1-22.

Hiscock P. 2008. The archaeology of ancient Australia. Routledge, London.

Holliday TW, Franciscus RG. 2009. Body size and its consequences: Allometry and the lower limb length of Liang Bua 1 (Homo floresiensis). J Hum Evol 57(3):223-228.

Hyodo M. 2011. High resolution record of the Matuyama-Brunhes transition constrains the age of Javanese Homo erectus in the Sangiran dome, Indonesia. Proc Natl Acad Sci 108. 
Indriati E, Swisher III CC, Lepre C, Quinn RL, Suriyanto RA, Hascaryo AT, Grün R, Feibel CS, Pobiner BL, Aubert M, Lees W, Antón SC. 2011. The age of the 20 meter Solo River Terrace, Java, Indonesia and the survival of Homo erectus in Asia. PLoS One 6(6):e21562.

Jungers WL, Harcourt-Smith WEH, Wunderlich RE, Tocheri MW, Larson SG, Sutikna T, Awe Due R, Morwood MJ. 2009b. The foot of Homo floresiensis. Nature 459:81-84.

Jungers WL, Larson SG, Harcourt-Smith W, Morwood MJ, Sutikna T, Awe Due R, Djubiantono T. 2009a. Descriptions of the lower limb skeleton of Homo floresiensis. J Hum Evol 57:538-554.

Kaifu Y, Aziz F, Indriati E, Jacob T, Kurniawan I, Baba H. 2008. Cranial morphology of Javanese Homo erectus: new evidence for continuous evolution, specialization, and terminal extinction. J Hum Evol 55(4):551580 .

Kaifu, Y, Baba H, Aziz F, Indriati E, Schrenk F, Jacob T. 2005. Taxonomic affinities and evolutionary history of the early Pleistocene hominins of Java: dentognathic evidence. Am J Phys Anthrop 128:709-726.

Keinan A, Mullikin JC, Patterson N, Reich D. 2007. Measurements of the human allele frequency spectrum demonstrates greater genetic drift in East Asians than in Europeans. Nat Genet 29:1251-1255.

Kubo D, Kono RT, Kaifu Y. 2013. Brain size of Homo floresiensis and its evolutionary implications. Proc $R$ Soc Ser B 280(1760):1-9.

Lahr MM. 1996. The evolution of modern human diversity: A study of cranial variation. Cambridge: Cambridge University Press.

Larick R, Ciochon RL, Zaim Y, Sudijono S, Rizal Y, Aziz F, Reagan M, Heizler M. 2001. Early Pleistocene 40AR/39Ar ages for Bapang Formation hominins, Central Java, Indonesia. Proc Natl Acad Sci 98:4866-4871.

Leigh SR. 1992. Cranial capacity evolution in Homo erectus and early Homo sapiens. Am J Phys Anthrop 87:1-13.

Macintosh NWG, Larnach SL. 1976. Aboriginal affinities looked at in world context. In: Kirk RL, Thorne AG, editors. The origins of the Australians. Canberra: Australian Institute of Aboriginal Studies Press. pp. 113-126.

Merriwether DA, Hodgson JA, Friedlaender FR, Allaby R, Cerchio S, Koki G, Friedlaender JS. 2005. Ancient mitochondrial M haplogroups identified in the Southwest Pacific. Proc Natl Acad Sci 102:13034-13039. 
Morwood MJ, Brown P, Jatmiko, Sutikna T, Wahyu Saptomo E, Westaway KE, Rokus Awe Due, Roberts RG, Maeda T, Wasisto S, Djubiantono T. 2005. Further evidence for small-bodied hominins from the late Pleistocene of Flores, Indonesia. Nature 437:1012-1017.

Morwood MJ, O'Sullivan PO, Susanto EE, Aziz F. 2003. Revised age of Mojokerto 1, an early Homo erectus cranium from East Java, Indonesia. Austral Archaeol 57:1-4.

Morwood MJ, Soejono RP, Roberts RG, Sutikna T, Turney CSM, Westaway KE, Rink WJ, Zhao J-X, Van den Bergh GD, Awe Due R, Hobbs DR, Moore WM, Bird MI, Fifield LK, 2004. Archaeology and age of a new hominin from Flores in eastern Indonesia. Nature 431:1087-1091.

O'Connor S, Ono R, Clarkson C. 2011. Pelagic fishing at 42,000 years before the present and the maritime skills of modern humans. Science 334(6059):11171121.

Olley, J. M., Roberts, R. G., Yoshida, H., \& Bowler, J. M. 2006. Single-grain optical dating of grave-infill associated with human burials at Lake Mungo, Australia. Quaternary Science Reviews, 25(19), 2469-2474.

Oppenheimer S. 2004. Out of Eden: The peopling of the world. London: Robinson Publishing.

Oppenoorth WFF. 1932. Homo (Javanthropus) Soloensis. Een Plistoceene mensch van Java. Wetensch. Meded. Van den Dienst van den Mijnbouw NederlandschIndië, No. 20:49-63.

Pugach I, Delfina F, Gunnarsdóttira E, Kayserd M, Stoneking M. 2013. Genomewide data substantiate Holocene gene flow from India to Australia. Proc Natl Acad Sci 110(5):1803-1808.

Rasmussen M, Guo X, Wang Y, Lohmueller KE, Rasmussen S, Albrechtsen A ... \& Krogh A. 2011. An Aboriginal Australian genome reveals separate human dispersals in Asia. Science 334(6052):94-98.

Rightmire GP. 1990. The evolution of Homo erectus: Comparative anatomical studies of an extinct human species. Cambridge: Cambridge University Press.

Rightmire GP. 1991. The dispersal of Homo erectus from Africa and the emergence of more modern humans. J Anthropol Res 47:177-191.

Robinson JT. 1953. Meganthropus, australopithecines, and hominids. Am J Phys Anthrop 11:1-38. 
Taxonomic Tapestries

Robinson JT. 1955. Further remarks on the relationship between "Meganthropus" and australopithecines. Am J Phys Anthrop 13:429-446.

Rightmire GP. 1994. The relationship of Homo erectus to later middle Pleistocene hominids. Cour Forsch-Inst Senckenberg 171:319-326.

Santa Luca AP. 1980. The Ngandong fossil hominids: A comparative study of a Far Eastern Homo erectus group. Yale Univ Publ Anthropol 78.

Stone T, Cupper ML. 2003. Last Glacial Maximum ages for robust humans at Kow Swamp, southern Australia. J Hum Evol 45(2):99-111.

Storm P. 2000. The evolutionary history of humans in Australasia from an environmental perspective. Anthropol Sci 108:225-244.

Storm P. 200la. Life and death of Homo erectus in Australasia: An environmental approach to the fate of a paleospecies. In: Sémah F, Falguères C, GrimaudHervé D, and Sémah A-M, editors. Origine des Peuplements et Chronologie des cultures Paléolithiques dans Le Sud-Est Asiatique. Paris: Semenanjung. pp. 279-298.

Storm P. 2001b. The evolution of humans in Australasia from an environmental perspective. Palaeogeogr Palaeoclimatol Palaeoecol 171:363-383.

Thorne A. 1976. Morphological contrasts in Pleistocene Australians. In: Kirk RL, Thorne AG, editors. The origin of the Australians. Canberra: AIAS Press. pp. 95-112.

Thorne A, Wolpoff MH. 1981. Regional continuity in Australasian Pleistocene hominid evolution. Am J Phys Anthrop 55:337-349.

Tobias PV, von Koenigswald GHR. 1964. A comparison between the Olduvai hominines and those of Java and some implications for hominid phylogeny. Nature 204:515-518.

Tocheri M, Orr CM, Larson SG, Sutikna T, Jatmiko, Saptomo EW, Rokus Awe Due, Djubiantano T, Morwood MJ, Jungers WI. 2007. The primitive wrist bone of Homo. floresiensis and its implications for hominin evolution. Science 317:1743-1745.

Tyler DE, Krantz GS, Sartono S. 1995. The taxonomic status of the 'Meganthropus' cranial (Sangiran 31) and the 'Meganthropus' occipital fragment III. In: Bower JRF, Sartono S, editors. Evolution and ecology of Homo erectus. Leiden: Pithecanthropus Centennial Foundation, Leiden University. pp. 189-201. 
van den Bergh GD. 1999. The late Neogene elephantoid-bearing faunas of Indonesia and their palaeozoogeographic. A study of the terrestrial faunal succession of Sulawesi, Flores, and Java, including evidence for early hominid dispersal east of Wallace's Line implications. Scripta Geol 117:1-419.

van den Bergh GD, de Vos J, Sondaar PY. 2001. The late Quaternary palaeogeography of mammal evolution in the Indonesian archipelago. Palaeogeogr Palaeoclimatol Palaeoecol 171:385-408.

Van den Bergh GD, de Vos J, Sondaar PY, Aziz F. 1996. Pleistocene zoogeographic evolution of Java (Indonesia) and glacio-eustatic sea level fluctuations: A background for the presence of Homo. Bullindo Pac Pre hi 14:7-21.

Van Holst Pellekaan. 2013. Genetic evidence for the colonization of Australia. Quatern Int 285:44-56.

Von Koenigswald GHR. 1956. Meeting prehistoric man. London: Thames and Hudson.

Webb SG. 1990. Cranial thickening in an Australian hominid as a possible palaeoepidemological indicator. Am J Phys Anthrop 82(4):403-411.

Webb SG. 2006. The first boat people. Cambridge: Cambridge University Press.

Weidenreich F. 1943. The skull of Sinanthropus pekinensis: A comparative study on a primitive hominid skull. Palaeontol Sin NS D 10.

Westaway, M.C. 2006. The Pleistocene human remains collection from the Willandra Lakes World Heritage Area, Australia, and its role in understanding modern human origins. National Science Museum Monographs No. 34. Tokyo: National Science Museum.

Westaway MC, Groves CP. 2009 The Mark of Ancient Java is on none of them. Archaeol Oceania 44:84-95.

Westaway MC, Lambert D. 2014. Origins of the First Australians. In: Smith C, editor. The global atlas of archaeology. New York: Springer.

Widianto H, Zeitoun V. 2003. Morphological description, biometry and phylogenetic position of the skull of Ngawi 1 (East Java, Indonesia). Int $J$ Osteoarchaeol 13:339-351.

Wood BA and Collard M. 1999. The human genus. Science 284:65-71.

Wright RVS. 1976. Evolutionary process and semantics: Australian prehistoric tooth size as a local adjustment. In: Kirk RL, Thorne AG, editors. The origin of the Australians. Canberra: AIAS Press. pp. 265-274. 
Taxonomic Tapestries

Zeitoun V. 2009. The human canopy: Homo erectus, Homo soloensis, Homo pekinensis and Homo floresiensis. BAR International Series 1937. Oxford: John and Erica Hedges Ltd.

Zeitoun V, Detroit F, Grimaud-Herve D, Widianto H. 2010. Solo man in question: Convergent views to split Indonesian Homo erectus in two categories. Quaternary International 223-224:281-292. 